Document downloaded from:

http://hdl.handle.net/10251/166917

This paper must be cited as:

Vicedo Payà, P.; Gil Gómez, H.; Oltra Badenes, RF.; Guerola-Navarro, V. (2020). A bibliometric overview of how critical success factors influence on enterprise resource planning implementations. Journal of Intelligent \& Fuzzy Systems. 38(5):5475-5487. https://doi.org/10.3233/JIFS-179639

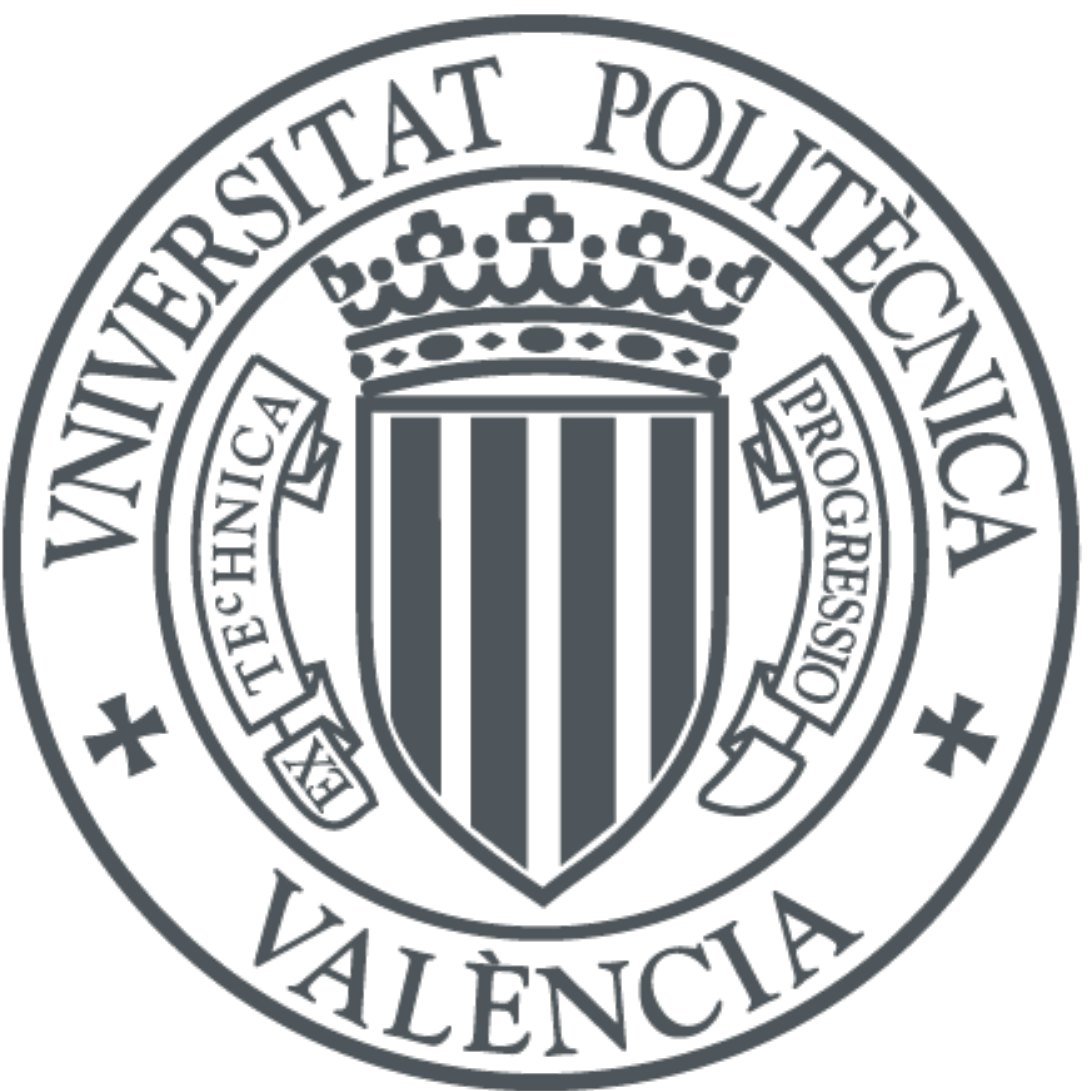

The final publication is available at

https://doi.org/10.3233/JIFS-179639

Copyright IOS Press

Additional Information 


\title{
A bibliometric overview of how critical success factors influence on enterprise resource planning implementations
}

\author{
Pau Vicedo*, Hermenegildo Gil, Raúl Oltra-Badenes and Vicente Guerola-Navarro \\ Department of Business Organization, Universitat Politècnica de València, Camí de Vera s/n, 46022 València, \\ Spain
}

\begin{abstract}
This work conducts bibliometric research into publications during the period 1999 to early 2018. The aim of this study is to help gain a better understanding of the publications covering CSF and ERP implementations all over the world. The study includes the most cited articles, most cited authors and most influential institutions as well as the most prolific countries. A database of 301 articles from 86 different institutions and 48 countries has been documented and analyzed. The results indicate that this field is growing significantly over time and a small number of US institutions are currently the most productive in this field.
\end{abstract}

Keywords: CSF, ERP, bibliometrics, Web of Science

\section{Introduction}

The process of digitalization and globalization means that companies now have to make faster decisions in order to survive. Small and Medium-sized Enterprises (SMEs) have found in Enterprise Resource Planning Systems (ERP) a key tool to adapt to this dynamic scenario. ERP systems provide realtime information about the company, such as planning, production and customer response among others These systems are revolutionizing the organizations [1], and they are the main reference for decision making and to quickly adapt to market changes. However, it is not enough to implement an ERP within a company to accomplish the goals, if the company wants to survive or grow Many of the implementations have been classified as failures because they did not achieve predetermined corporate goals. There are several factors that can lead to success or failure [2], and these factors, known as Critical Success Factors (CSF), are defined as a necessary fact or element to achieve a particular goal. Therefore, CSFs are a crucial element to successfully implement ERPs, and thus it is crucial to ensure that they are identified and correctly dealt with.

Bibliometrics is defined by [3] as the discipline that studies bibliographic material quantitatively. There are many bibliometric studies in the literature mainly focused on analysis of specific Journals [22] [23] [24] [25] [27] [28] [29] [30] [31] [32] [33] [34] [35] [37] [38] [39] [40] and [41] Much of this work also looks at research fields such as innovation [43], research disciplines [36] and management sciences [26]. Among them the reader can find a number of different approaches. For example, [21] and [23] presented an analysis of influential countries based on number of studies cited. Several studies, such as [29] use thresholds to better identify the impact of each study, and they generally cover between over 100, 50, $20,10,5$ and 1 citations. [31] also relates the population of the countries and the number of citations to identify which are the most productive countries and [32] introduces de $h$-index, while [22], [23] and [33] introduce co-citation including document co-citation, author co-citation and institute co-citation. It is also worth highlighting that [22], [23] and [30] also use

\footnotetext{
*Corresponding author. E-mail: pavipa@upv.es
} 
VOS Viewer software for graphical representation of the bibliometric results.

It is important to highlight that all of the above cited articles use the Web of Science as a core database to analyze bibliometric data.

Starting from their inception, ERP systems and their CSFs for successful implementation have produced a substantial number of published research papers ongoing studies [13]. The aim of this work is to synthesize the existing scientific bibliography into a bibliometric study, from a general perspective regarding leading institutions, authors, journals, countries and the most cited articles, all of which use indexes that help to provide a better understanding of the state of the art and also to highlight trends in the field of study. This study was motivated by a number of different factors. Firstly, the aim was to provide value in a field where there is not yet a large number of studies but which is in continuous growth due to business evolution and digitization. Secondly, this work aims to help researchers and authors to find the most influential actors, whether they be authors, countries or institutions, in the field that might help them to focus their research in a more effective way. Finally, it is necessary to identify which journals publish more on this type of article and their influence.

The authors believe that interest on this work will grow as the reader sees the evolution in the number of published articles within the last 18 years (Fig. 1), It is clear that interest and research in the field are growing. It is also hoped that the characterization of the CSF for ERP implementation publications provided in this article will serve as a basis for future, more extensive research, such as other articles or $\mathrm{PhD}$ research.

The main database in scientific research contributions is the Web of Science (WoS) which is the core of this work, however, WoS is a live database which is continuously growing and adding more publications, and for this reason only existing publications from between 1999 and January 2018 have been considered. This study provides an overview of the evolution of the studies published over this period, the 50 most cited papers, the most influential universities and authors, the journals publishing in this field and, finally, the most productive countries, considering both citations and publications. Prior to the results there is a section describing the methods used and following this, the conclusions are presented.

\section{Methods}

Studying and reviewing the literature on a specific topic gives an overview of research trends and its impact on the field [9] [17]. The current study considered all the publications over the years published on Web of Science (WoS), however only articles and reviews since 1999 have been found and only published studies during complete natural years have been considered. Although, there are other Academic databases, such as Google Scholar and Scopus, WoS is generally considered to be the best academic database on research contributions [20]. It contains more than 15,000 journals, over 90,000,000 records and covers up to 273 disciplines.

In bibliometric studies [19] [10] [14] a wide variety of methods are used but the most common indicators are the number of citations and the amount of publications. In this study, those two indicators were considered together with the H-index, a new index introduced by Hirsch [4], which integrates publications and citations into one single index. Other indexes were also considered in order to define the impact of each article [18], the ratio (citations / articles), and for each institution the ratio (times cited / total studies). Moreover, as [5] stated, the number of articles above a citation threshold allows the researcher to identify influential articles, which is why different thresholds are considered in the results. Additionally, it is important to identify the quality of the institution [15] because this indicates the importance and impact of an article. For this reason, the reputed Academic Ranking of World Universities [5] and the QS World University Rankings [6] were consulted to identify the quality of the institution. Finally, a study on which journals [16] publish work on this topic was conducted to complete the picture regarding the state of the art. 


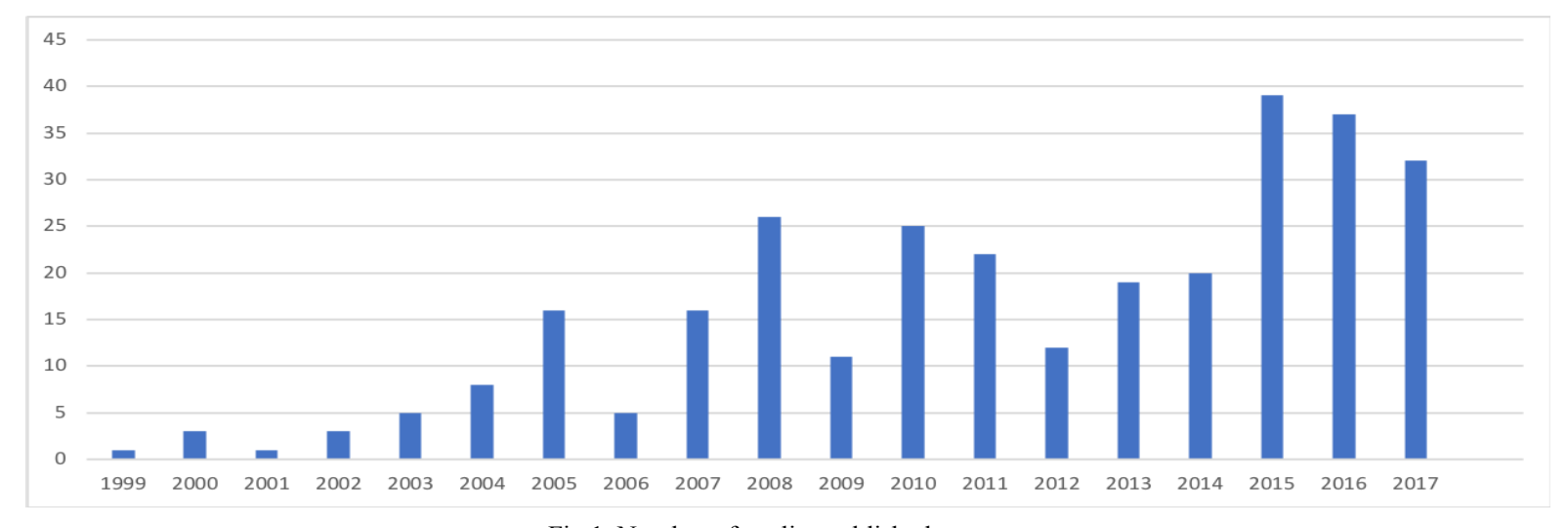

Fig 1. Number of studies published per year

When conducting the study some limitations were applied in order to narrow the results to the specific field of study. Therefore, a selection of keywords related to the topic was done. The keywords considered are: ERP, CSF, Enterprise Resource(s) Planning, Critical Success Factor(s) and Enterprise System(s). This generated 549 references not all of which were related to the main topic, consequently not all categories have been taken into account, only those within the field of study: computer science information systems, management, information science library science, operations research management science, computer science interdisciplinary applications, business, engineering industrial, computer science theory methods, engineering manufacturing, computer science artificial intelligence, engineering electrical electronic, economics, computer science software engineering, engineering multidisciplinary, business finance, computer science hardware architecture, telecommunications, social sciences interdisciplinary, computer science cybernetics, automation control systems, planning development, engineering mechanical and ergonomics reducing the amount of publications to 491 and then only the article (287 papers) and reviews (15) were taken, leaving a final total of 301 research works. The study used the material available on WoS in January 2018.

For a better result understanding, this article also includes a graphical analysis of the bibliographic material by using the VOS Viewer software [42]. This software draws maps based on the collected data from WoS based on citation and co-citation, coupling and co-authorship among others [22].

\section{Results}

In this section the most significant results of the bibliometric analysis are presented. Following the indicated keywords and related categories of study, 491 references were found including 287 articles, 17 book chapters, 199 proceedings papers, 15 reviews, 2 editorial materials and 1 book. These works have a total number of citations of 8999 with a ratio (cites / studies) of 18.33, the h-index is 44 .

In order to narrow the results only the articles and reviews have been considered making a total of 301 references, since these options are the ones which can be considered as pure scientific contributions. Thus 8817 citations with a ratio (cites / studies) of 29.29 and a h-index of 44 were obtained.

\subsection{Evolution of published studies}

The first study found was published in 1999, and was the only one published that year. As can be seen in Fig. 1 the number of studies increased slowly up to a total of 24 in 2008 with the exception of 2006 where only 5 studies were published. After 4 years of decreasing number of publications, they increased again, until reaching their maximum during the years 2015 and 2016 with 35 publications followed by a minor decline in 2017. The gradual increase of publications it is due to two main factors, the first of which is the increase in researchers worldwide and the second and main reason is the digitalization of society. Increasingly, it is clear that companies need more upto-date information to make decisions faster and to be able to adapt to the market changes, and it is here that ERP systems gain relevance as the scientific community gains awareness of how the world is evolving.

Analyzing the citations in Table 1. General citations per year, it can be seen that the most cited articles are not the ones published more recently. The year 2007 was the year with the most citations with 1464, other years with more than 1000 citations were 2003, 2005 and 2008. This is not related to the num- 
ber of articles published which increase almost every year.

\subsection{0 most cited papers published}

Table 1. General citation per year

\begin{tabular}{lllllllll}
\hline Year & $\geq 100$ & $\geq 50$ & $\geq 20$ & $\geq 10$ & $\geq 5$ & $\geq 1$ & TS & TC \\
\hline 1999 & 1 & 0 & 0 & 0 & 0 & 0 & 1 & 351 \\
2000 & 1 & 1 & 0 & 0 & 0 & 1 & 3 & 243 \\
2001 & 0 & 0 & 1 & 0 & 0 & 0 & 1 & 35 \\
2002 & 2 & 1 & 0 & 0 & 0 & 0 & 3 & 776 \\
2003 & 3 & 0 & 0 & 1 & 1 & 0 & 5 & 1009 \\
2004 & 3 & 2 & 2 & 0 & 0 & 0 & 8 & 725 \\
2005 & 4 & 4 & 3 & 1 & 1 & 2 & 16 & 1120 \\
2006 & 1 & 1 & 1 & 2 & 0 & 0 & 5 & 243 \\
2007 & 3 & 2 & 5 & 4 & 1 & 0 & 16 & 1470 \\
2008 & 2 & 4 & 13 & 4 & 0 & 3 & 26 & 1126 \\
2009 & 0 & 2 & 4 & 0 & 4 & 0 & 11 & 288 \\
2010 & 0 & 2 & 7 & 6 & 3 & 5 & 25 & 467 \\
2011 & 0 & 0 & 3 & 4 & 2 & 9 & 22 & 188 \\
2012 & 0 & 0 & 2 & 5 & 2 & 2 & 12 & 165 \\
2013 & 0 & 2 & 2 & 6 & 4 & 3 & 19 & 263 \\
2014 & 0 & 0 & 0 & 4 & 10 & 5 & 20 & 151 \\
2015 & 0 & 0 & 1 & 0 & 8 & 21 & 39 & 126 \\
2016 & 0 & 0 & 0 & 0 & 4 & 15 & 37 & 53 \\
2017 & 0 & 0 & 0 & 0 & 1 & 8 & 32 & 18 \\
\hline Total & 20 & 21 & 44 & 37 & 41 & 74 & 301 & 8817 \\
\hline$\%$ & 6,64 & 6,69 & 14,62 & 12,29 & 13,62 & 24,58 & 100 & \\
\hline
\end{tabular}

Abbreviations: $\geq 100=$ Number of documents with equal or more than 100 citations; $\geq 50=$ Number of documents with equal or more than 50 citations; $\geq 20=$ Number of documents with equal or more than 20 citations; $\geq 10=$ Number of documents with equal or more than 10 citations; $\geq 5=$ Number of documents with equal or more than 10 citations; $\geq 1=$ Number of documents with equal or more than 1 citations; $\mathrm{TS}=$ Total studies; $\mathrm{TC}=$ Total citations; $\mathrm{PCT}=$ Percentage.

It is important to know which were the most cited papers because this can define how influential they have been to others. Table 2 lists the most cited publications in descending order, it can be observed that the most cited article, Liang, Huigang; Saraf, Nilesh; $\mathrm{Hu}$, Qing; et al. (2007), has 817 citations with an average of 74.27 citations per year. The second is Umble, EJ; Haft, RR; Umble, MM (2003) with 513 citations and average of 34.20 citations per year.

There are 20 publications with over 100 citations each, all but one of which is from the first decade of the century. Looking further to the rest of the list it can be also stated that, again, all of the publications are from the same decade but one, and it has to be mentioned that the least cited research work has a significant number with 42 citations.

Fig. 2 shows graphically, by using the VOS Viewer software, the map of citations between articles (A cites $B$ and $B$ cites $A$ ) with a minimum threshold of one hundred citations. This figure demonstrates in a straightforward way which are the most influential articles.

\subsection{Most productive and influential institutions}

Table 3 shows the 50 most productive institutions worldwide in this case the number of publications, times cited, h-index and the ratio (times cited / total studies) are considered together with the most relevant number of papers above the given thresholds 100,50 and 20 and the current global ranking at both, Academic Ranking of World Universities (ARWU) and Quacquarelli Symonds QS World University Rankings [12]. This helps the reader to have an idea of the real influence of each university. The top influential Universities are Florida Atlantic University from United States, Wayne State University from United States, University of Manchester from United Kingdom, University of Nebraska Lincoln from United States and the City University of Hong Kong from China, all of them above 300 citations overall. Regarding production, the University of Pablo de Olavide from Spain is the first with 8 total papers and the highest h-index 6 , which means they have 6 articles with at least 6 citations each. Following this are the University of Ljubljana from Slovenia with 7 studies and Ryerson University from Canada and national Central University from Taiwan with 6 papers each.

The universities from the United States are the most listed with 12 appearances followed by United Kingdom (which includes the works published under England, Scotland, Wales and Northern Ireland) with 7, Canada with 6 , and Taiwan, Iran and China with 4 each. Even though the most listed institutions listed are from countries such as US, UK, Canada and Australia it can be stated that European and Asian Universities are increasing their work in this field. This is due to the rise of Asian universities which are committed to technology research and how to apply it to the business environment. However, most of the universities are from English speaking countries.

Looking at the ARWU, 6 institutions are in the top 100 but only 2 of them are in the top 50: University of Manchester in position 38 and University of Melbourne in position 39. There are 17 universities which are not even listed in the ranking. Regarding the QS ranking, only one, National University of Singapore, is in the top 20 and City University of Hong Kong, University of Manchester and University of Melbourne are in the top 50. Between the 50 and 100 positions there are 5 more universities. Therefore, it can be stated that only few of those considered to be the best universities worldwide are not publishing on this topic. 


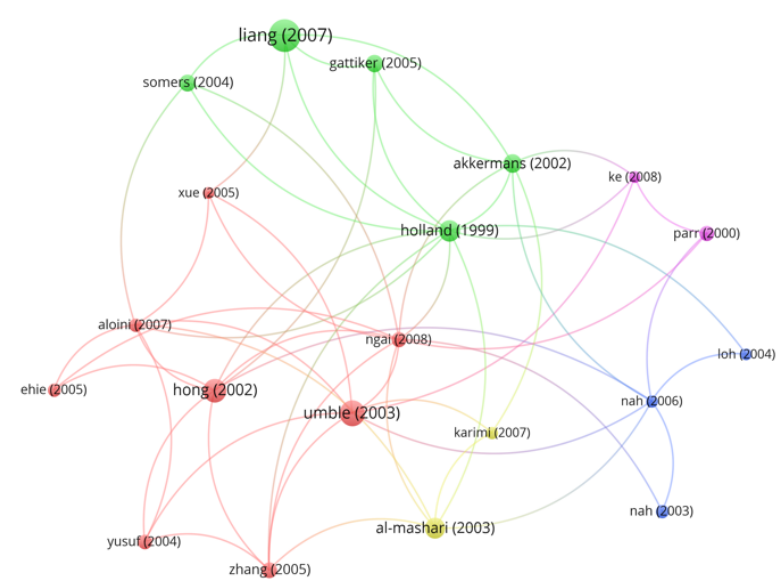

Fig 2. Citation between most influential articles

\subsection{Most productive and influential authors}

As with institutions, there are authors from around the world publishing about ERP and their CSFs for successful implementations. Table 4 presents the 50 most influential authors ordered by highest number of citations. As with the other sections, the h-index, the times cites, total studies and the ratio (cites / studies) appear to have been presented in order to get a better picture of their production and influence. Table 4 also includes the University/Institution where their last paper was submitted to the WoS and their country.

As shown in Table 4, Americans are the most cited authors with 8 out of the top 10, Liang and Xue share first position as they co-authored the most cited paper with 930. The first non-American author is the Chinese Law with 214 citations followed by the Spaniard Salmeron with 196, who is the most productive author with 7 published papers. English-speaking authors from US and UK occupy 18 of the top 22 places in the list emphasizing the importance of AngloSaxon countries in this field of research. Also noteworthy are the Spanish authors who have 3 places in the top 20, and among the most productive with a published number of papers and the University with more top authors are Ryerson University from Canada and Universidad Pablo de Olavide from Spain with three each.

\subsection{Most productive and influential countries}

WoS presents work from all around the world and, since the topic is general and not related to any geographical area, 48 countries are presented in Table 5. In this analysis the population in thousands [8] and the relationship between the total studies and cita- tions to the inhabitants in millions to identify the productivity of each country have also been included. Furthermore, the same indexes as those used in the previous tables are used here as well. Note that the countries listed refer to the country where the author was working at the time of the publication.

As expected for the quality of their work, and already stated by the reviewed literature [21], the importance of their institutions and its size the US is the number one in terms of works (77) and times cited (4083) with an h-index of 29. The UK follows with 34 studies and 1613 citation with an h-index of 16 . In 6 th position we can find Taiwan with similar amount of works with 31 but less citations (568) which translates into that there is no relation to having a large amount of publications and being influential. Before Taiwan, there are UK, Canada, China and South Korea.

Nonetheless, the most productive country per inhabitant is Canada followed by Taiwan in second and UK in third position. It is worth highlighting that 4 out of the first 7 countries are English speaking countries and they represent over $51 \%$ of all studies. Asian countries, like China, South Korea and Taiwan, compete for the lead with the English-speaking countries. It is surprising that India, with great Universities and a large population, does not appear in the leading positions and is only stays in 26th place. On the other hand, the rest of the results are fairly diverse which shows that business digitalization is a global concern with several countries from Middle East, Europe, South Africa and Namibia from Africa and Colombia from South America.

\subsection{Publishing Journals}

In this section an overview of the journals [11] publishing in this field is given. Table 6 shows the journals with the highest number of publications on this field. At the top of the list is Enterprise Information Systems with 15 articles published, followed by International Journal of Production Economics with 14 and Computers in Industry and Journal of Computer Information Systems with 12.

On the other hand, the list varies when considering citations. In this case MIS Quarterly is first with 1143 citations followed by Information Management (965), European Journal of Operational Research (866), International Journal of Production Economics (864) and European Journal of Information Systems (473). 


\section{Conclusions}

This study gives a general overview of the works published about ERP implementation and its CSFs on the WoS. The results show how the number of publications has increased over time from 1 in 1999 to more than 30 since 2015, and this has happened due to the continuous digitalization of the business world and the need for quality data in order to make faster decisions. The US leads the publications because they are home to the main universities but Asian countries follow closely. It is worth highlighting the importance of Taiwan in this field with its strong position and important number of publications and citations. In the following positions we see other English-speaking countries such as Australia, United Kingdom and Canada which leads the contributions per inhabitant. Not without cause, the most reputed institutions in this field belong to Taiwan, Spain, Canada, Slovenia and Hong Kong displacing American universities from the top. Developing countries do not appear in the leading positions but they are beginning to publish also in this field.

Regarding the journals, it is important to highlight that the most cited ones are not the most productive. The most cited article was published in MIS Quarterly which is one of the most important journals in the field. Moreover, the authors of that article, Liang and Xue, are also considered the most influential and their university, Florida Atlantic University, is also the first in institutions. Therefore, their article is considered the most important article with strongest impact on other research.

Observing the number of published studies and the citations generated, an objective view of the evolution that the research on this field has had during the last 18 years begins to emerge. I

$\mathrm{t}$ is worth noting that the work provides a general overview using a wide range of indicators including amount of publications, citations, h-index and several citation thresholds. This is due to the lack of an optimal standardized way of analyzing bibliometric results and, therefore, different research groups may be interested in different indicators considering different perspectives.

This article is intended to be the starting point for future research in the field of successful ERP implementations by delineating information sources.

\section{References}

[1] M. Bradford and J. Florin. "Examining the role of innovation diffusion factors on the implementation success of enterprise resource planning systems". International Journal of Accounting Information Systems, 4(3):205-225, September 2003.

[2] J Hedman. "ERP systems: Critical factors in theory and practice". Center for Applied ICT (CAICT), CBS, Frederiksberg, 2010.

[3] R Broadus. "Toward a definition of "bibliometrics"". Scientometrics, 12(5-6):373-379, 1987.

[4] JE. Hirsch. "An index to quantify an individual's scientific research output". Proceedings of the National academy of Sciences of the United States of America, 102(46):16569, 2005.

[5] JM. Merigó, AM. Gil-Lafuente, and RR. Yager. "An overview of fuzzy research with bibliometric indicators". Applied Soft Computing, 27:420-433, February 2015.

[6] Academic Ranking of World Universities. Shanghai Ranking Consultancy.

http://www.shanghairanking.com/arwu2017.html, January 2018.

[7] QS World University Rankings. QS Quacquarelli Symonds Limited. https://www.topuniversities.com/university- rankings/world-university-rankings/2018, January 2018.

[8] The World

Bank https://data.worldbank.org/indicator/sp.pop.totl, January 2018.

[9] Anguinis, H. Suárez-González, I. Lannelongue, G. Joo, H. "Scholarly Impact Revisited". Academy of Management Perspectives. $105-132$

[10]T. Dereli, A. Durmuğ, D. Delibas , \& N Avlanmaz (2011): "An analysis of the papers published in Total Quality Management \& Business Excellence from 1995 through 2008", Total Quality Management \& Business Excellence, 22:3, 373-386

[11]CG. Petersen, GR. Aase, DR. Heiser, (2011), "Journal ranking analyses of operations management research", International Journal of Operations \& Production Management, Vol. 31 ISS: 4 pp. $405-422$

[12] M. Maloni, CR. Carter, L. Kaufmann, (2012), "Author affiliation in supply chain management and logistics journals: 2008 2010", International Journal of Physical Distribution \& Logistics Management, Vol. 42 No 1, pp. $83-100$

[13]PN. Hsieh, PL. Chang, (2009), "An assessment of world- wide research productivity in production and operations management", International Journal of Production Economics, Vol. 120 , pp. $540-551$

[14]MT. García Merino, ML. Pereira do Carmo, M Valle Santos Álvarez (2016), "25 Years of Technovation: Characterisation and evolution of the journal", Technovation, Vol. 26, pp.1303 $-1316$

[15]PM. Podsakoff, SB. MacKenzie, NP. Podsakoff and DG. Bachrach (2008), "Scholarly Influence in the Field of Management: A Bibliometric Analysis of the Determinants of University and Author Impact in the Management Literature in the Past Quarter Century", Journal of Management, Vol. 34, pp. $641-720$

[16]CH. Goh, CW. Holsapple, L. Ellis Johnson, JR. Tanner (1997), "Evaluating and classifying POM journals", Journal of Operations Management, 15, pp $123-138$

[17]A. Pilkington, J. Meredith (2008), "The evolution of the intellectual structure of operations management 1980 - 2006: A citation/co-citation analysis", Journal of Operations Management, Vol. 27, pp. $185-202$

[18]JS. Stonebraker, E. Gil, CW. Kirkwood, RB. Handfield (2012), "Impact factor as a metric to assess journals where OM re- 
search is published", Journal of Operations Management, Vol. 30 , pp. $24-43$

[19]J. Fagerberg, M. Fosaas, K. Sapprasert (2012), "Innovation: Exploring the knowledge base", Research Policy, Vol. 41, pp. $1132-1153$

[20]WL. Shiau, YK. Dwivedi, CH. Tsai (2015), "Supply chain management: exploring the intellectual structure", Sciencentometrics, Vol. 105 , pp. $215-230$

[21]JM. Merigó, CA. Cancino, F. Coronado, D. Urbano (2016) "Academic research in innovation: a country analysis", Sciencentometrics, Vol. 108, pp. 559 - 593

[22]C. Cancino, JM. Merigó, F. Coronado, Y. Dessouky \& M Dessouky, (2017). "Forty years of Computers \& Industrial Engineering: A bibliometric analysis". Computers \& Industrial Engineering, 113, 614 - 629.

[23]S. Laengle, JM Merigó, J. Miranda, R. Slowinski, I. Bomze, E. Borgonovo, RG. Dyson, JF. Oliveira, \& R. Teunter, (2017) "Forty years of the European Journal of Operational Research: A bibliometric overview". European Journal of Operational Research, 262(3), 803 - 816.

[24]FJ. Martínez-López, JM. Merigó, L. Valenzuela \& C. Nicolás, (2018). "Fifty years of the European Journal of Marketing: A bibliometric analysis". European Journal of Marketing, 52(12), 439 - 468 .

[25]JM. Merigó, W. Pedrycz, R. Weber \& C. de la Sotta, (2018). "Fifty years of Information Sciences: A bibliometric overview". Information Sciences, 432, 245 - 268.

[26] JM. Merigó, JB. Yang, (2017b). "A bibliometric overview of operations research \& management science". Omega - International Journal of Management Science, 73, 37 - 48

[27]A. Tur-Porcar, A. Mas-Tur, JM. Merigó, N. Roig-Tierno, J. Watt, (2018). "A bibliometric history of the Journal of Psychology between 1936 and 2015". Journal of Psychology, 152, 199 - 225.

[28]L. Valenzuela, JM. Merigó, W. Johnston, C. Nicolás, F. Jaramillo, (2017). "Thirty years of the Journal of Business \& Industrial Marketing: A bibliometric analysis". Journal of Business \& Industrial Marketing, 32(1), 1-18.

[29]JM. Merigó, F. Blanco-Mesa, AM. Gil-Lafuente, (2017). "Thirty years of the International Journal of Intelligent Systems: A Bibliometric Review". International Journal of Intelligent Systems. Vol 32, 526 - 554.

[30] W. Wang, S. Laengle, JM. Merigó, D. Yu, E. Herrera-Viedma, MJ. Cobo \& B. Bouchon-Meunier, (2018). "A Bibliometric Analysis of the First Twenty-Five Years of the International Journal of Uncertainty, Fuzziness and Knowledge-Based Systems". International Journal of Uncertainty, Fuzziness and Knowledge-Based Systems. Vol 26, No. 2 (2018) 169 - 193.

[31]JM. Merigó, W. Pedycz, R. Weber, C. de la Sotta, (2017) "Fifty years of Information Sciences: A bibliometric overview". Information Sciences 432 (2018) 245 - 268.

[32]D. Yu, Z. Xu, Y. Kao, CT. Lin, (2018). "The Structure and Citation Landscape of IEEE Transactions on Fuzzy Systems (1994 - 2015)". IEEE Transactions on Fuzzy Systems, Vol. 26, No. 2.

[33]M. Tang, H. Liao, SF. Su, (2018). "A Bibliometric Overview and Visualization of the International Journal of Fuzzy Systems Between 2007 and 2017". International Journal of Fuzzy Systems, 20(5):1403 - 1422 .

[34]AG. López-Herrera, E. Herrera-Viedma, MJ. Cobo, MA Martínez, (2012). "A conceptual snapshot of the first decade (2002 - 2011) of the International Journal of Information Technology and Decision Making". International Journal of Information Technology \& Decision Making, Vol. 11, No. 2 $247-270$.
[35]MJ. Cobo, MA. Martínez, M. Gutiérrez-Salcedo, H. Fujita, E. Herrera-Viedma, (2015). "25 years at Knowledge-Based Systems: A bibliometric analysis". Knowledge-Based Systems 80, $3-13$.

[36]D. Yu, S. Shi, (2015). "Researching the development of Atanassov intuitionistic fuzzy set: Using a citation network analysis". Applied Soft Computing 32, 189 - 198.

[37]D. Yu, Z. Xu, W. Pedrycz, W. Wang, (2017). "Information sciences 1968 - 2016: A retrospective analysis with text mining and bibliometric". Information Sciences 418 - 419, 619 634.

[38]D. Yu, Z. Xu, W. Wang, (2018). "Bibliometric analysis of fuzzy theory research in China: A 30-year perspective". Knowledge- Based Systems 141, 188 - 199.

[39]D. Yu, (2015). "A scientometrics review on aggregation operator research". Scientometrics 105:115 - 133.

[40]Y. Zhang, H. Chen, J. Lu, G. Zhang, (2017). "Detecting and predicting the topic change of Knowledge-Based Systems: A topic-based bibliometric analysis from 1991 to 2016". Knowledge-Based Systems 133, 255 - 268.

[41]PK. Muhuri, AK. Shukla, M. Janmaijaya, A. Basu, (2018). "Applied soft computing: A bibliometric analysis of the publications and citations during (2004 - 2016)". Applied Soft Computing 60, $381-392$.

[42] Van Eck, N. J., \& Waltman, L. (2010). Software survey: VOSviewer, a computer program for bibliometric mapping. Scientometrics, 84, 523-538.

[43]J. Fagerberg, M. Fosaas, K. Sapprasert (2012). "Innovation: Exploring the knowledge base". Research Policy 411132 1153 
Table 2. The 50 most cited articles

\begin{tabular}{|c|c|c|c|c|c|}
\hline $\mathbf{R}$ & TC & Title & Author/s & Year & $\mathbf{C} / \mathbf{Y}$ \\
\hline 1 & 817 & $\begin{array}{l}\text { Assimilation of enterprise systems: The effect of institutional pressures and the mediating role of top } \\
\text { management }\end{array}$ & $\begin{array}{l}\text { Liang, Huigang; Saraf, Nilesh; Hu, Qing; et } \\
\text { al. }\end{array}$ & 2007 & 74,27 \\
\hline 2 & 514 & Enterprise resource planning: Implementation procedures and critical success factors & Umble, EJ; Haft, RR; Umble, MM & 2003 & 34,27 \\
\hline 3 & 434 & The critical success factors for ERP implementation: an organizational fit perspective & Hong, KK; Kim, YG & 2002 & 27,13 \\
\hline 4 & 351 & A critical success factors model for ERP implementation & Holland, CP; Light, B & 1999 & 18,47 \\
\hline 5 & 330 & Enterprise resource planning: A taxonomy of critical factors & Al-Mashari, M; Al-Mudimigh, A; Zairi, M & 2003 & 22,00 \\
\hline 6 & 273 & $\begin{array}{l}\text { Vicious and virtuous cycles in ERP implementation: a case study of interrelations between critical } \\
\text { success factors }\end{array}$ & Akkermans, $\mathrm{H}$; van Helden, $\mathrm{K}$ & 2002 & 17,06 \\
\hline 7 & 240 & $\begin{array}{l}\text { What happens after ERP implementation: Understanding the impact of interdependence and differentia- } \\
\text { tion on plant-level outcomes }\end{array}$ & Gattiker, TF; Goodhue, DL & 2005 & 18,46 \\
\hline 8 & 223 & A taxonomy of players and activities across the ERP project life cycle & Somers, TM; Nelson, KG & 2004 & 15,93 \\
\hline 9 & 199 & A framework of ERP systems implementation success in China: An empirical study & Zhang, Z; Lee, MKO; Huang, P; et al. & 2005 & 15,31 \\
\hline 10 & 184 & A model of ERP project implementation & Parr, A; Shanks, G & 2000 & 10,22 \\
\hline 11 & 177 & Examining the critical success factors in the adoption of enterprise resource planning & Ngai, E. W. T.; Law, C. C. H.; Wat, F. K. T. & 2008 & 17,70 \\
\hline 12 & 169 & Enterprise information systems project implementation: A case study of ERP in Rolls-Royce & Yusuf, Y; Gunasekaran, A; Abthorpe, MS & 2004 & 12,07 \\
\hline 13 & 148 & Identifying critical issues in enterprise resource planning (ERP) implementation & Ehie, IC; Madsen, M & 2005 & 11,38 \\
\hline 14 & 146 & Risk management in ERP project introduction: Review of the literature & $\begin{array}{l}\text { Aloini, Davide; Dulmin, Riccardo; Mininno, } \\
\text { Valeria }\end{array}$ & 2007 & 13,27 \\
\hline 15 & 141 & ERP implementation: Chief Information Officers' perceptions of critical success factors & Nah, FFH; Zuckweiler, KM; Lau, JLS & 2003 & 9,40 \\
\hline 16 & 119 & The impact of ERP implementation on business process outcomes: A factor-based study & $\begin{array}{l}\text { Karimi, Jahangir; Somers, Toni M.; } \\
\text { Bhattacherjee, Anol }\end{array}$ & 2007 & 10,82 \\
\hline 17 & 117 & Critical success factors for enterprise resource planning implementation and upgrade & Nah, Fiona Fui-Hoon; Delgado, Santiago & 2006 & 9,75 \\
\hline 18 & 113 & $\begin{array}{l}\text { Critical elements for a successful enterprise resource planning implementation in small- and medium- } \\
\text { sized enterprises }\end{array}$ & Loh, TC; Koh, SCL & 2004 & 8,07 \\
\hline 19 & 109 & ERP implementation failures in China: Case studies with implications for ERP vendors & Xue, YJ; Liang, HG; Boulton, $\mathrm{K}$ & 2005 & 8,38 \\
\hline 20 & 105 & Organizational culture and leadership in ERP implementation & Ke, Weiling; Wei, Kwok Kee & 2008 & 10,50 \\
\hline 21 & 91 & $\begin{array}{l}\text { Determinants of the adoption of enterprise resource planning within the technology-organization- } \\
\text { environment framework: Taiwan's communications }\end{array}$ & Pan, Ming-Ju; Jang, Woan-Yuh & 2008 & 9,10 \\
\hline 22 & 84 & Understanding success and failure in customer relationship management & King, Stephen F.; Burgess, Thomas F. & 2008 & 8,40 \\
\hline 23 & 82 & A multi-project model of key factors affecting organizational benefits from enterprise systems & $\begin{array}{l}\text { Seddon, Peter B.; Calvert, Cheryl; Yang, } \\
\text { Song }\end{array}$ & 2010 & 10,25 \\
\hline 24 & 82 & $\begin{array}{l}\text { Perceived absorptive capacity of individual users in performance of Enterprise Resource Planning(ERP) } \\
\text { usage: The case for Korean firms }\end{array}$ & $\begin{array}{l}\text { Park, Jong-Hun; Suh, Hyun-Ju; Yang, Hee- } \\
\text { Dong }\end{array}$ & 2007 & 7,45 \\
\hline 25 & 77 & $\begin{array}{l}\text { Achievement assessment for enterprise resource planning (ERP) system implementations based } \\
\text { on critical success factors (CSFs) }\end{array}$ & Sun, AYT; Yazdani, A; Overend, JD & 2005 & 5,92 \\
\hline 26 & 76 & $\begin{array}{l}\text { Implications of the fit between organizational structure and ERP: A structural contingency theory per- } \\
\text { spective }\end{array}$ & Morton, Neil A.; Hu, Qing & 2008 & 7,60 \\
\hline 27 & 76 & Causes influencing the effectiveness of the post-implementation ERP system & $\mathrm{Yu}, \mathrm{CS}$ & 2005 & 5,85 \\
\hline 28 & 72 & Successful use of e-procurement in supply chains & Puschmann, $\mathrm{T}$ & 2005 & 5,54 \\
\hline 29 & 70 & Beyond critical success factors: A dynamic model of enterprise system innovation & King, SF; Burgess, TF & 2006 & 5,83 \\
\hline 30 & 69 & The role of information systems resources in ERP capability building and business process outcomes & $\begin{array}{l}\text { Karimi, Jahangir; Somers, Toni M.; } \\
\text { Bhattacherjee, Anol }\end{array}$ & 2007 & 6,18 \\
\hline 31 & 69 & Data quality issues in implementing an ERP & $\mathrm{Xu}, \mathrm{HJ}$; Nord, JH; Brown, N; et al. & 2002 & 4,31 \\
\hline 32 & 66 & ERP implementation at SMEs: analysis of five Canadian cases & $\begin{array}{l}\text { Snider, Brent; da Silveira, Glovani J. C.; } \\
\text { Balakrishnan, Jaydeep }\end{array}$ & 2009 & 7,33 \\
\hline 33 & 66 & Improving productivity and firm performance with enterprise resource planning & Beheshti, Hooshang M.; Beheshti, Cyrus M. & 2010 & 8,25 \\
\hline 34 & 65 & $\begin{array}{l}\text { An integrative framework for the assimilation of enterprise resource planning systems: Phases, anteced- } \\
\text { ents, and outcomes }\end{array}$ & Bajwa, DS; Garcia, JE; Mooney, T & 2004 & 4,64 \\
\hline 35 & 61 & Successful enterprise resource planning implementation: taxonomy of critical factors & Dezdar, Shahin; Sulaiman, Ainin & 2009 & 6,78 \\
\hline 36 & 60 & Aligning ERP implementation with competitive priorities of manufacturing firms: An exploratory study & Yen, HR; Sheu, C & 2004 & 4,29 \\
\hline 37 & 60 & Investigating success factors in enterprise application integration: a case-driven analysis & Lam, W & 2005 & 4,62 \\
\hline 38 & 57 & Enhancing manufacturing performance with ERP systems & Palaniswamy, R; Frank, T & 2000 & 3,17 \\
\hline 39 & 56 & TAM-based success modeling in ERP & Bueno, Salvador; Salmeron, Jose L. & 2013 & 11,20 \\
\hline 40 & 55 & A grey-based DEMATEL model for evalu & Bai, Chunguang; Sarkis, Joseph & 2013 & 11,00 \\
\hline 41 & 51 & $\begin{array}{l}\text { Implementation critical success factors (CSFs) for ERP: Do they contribute to implementation success } \\
\text { and post-implementation performance? }\end{array}$ & $\begin{array}{l}\text { Ram, Jiwat; Corkindale, David; Wu, Ming- } \\
\mathrm{Lu}\end{array}$ & 2013 & 10,20 \\
\hline 42 & 49 & $\begin{array}{l}\text { Unleashing the effectiveness of process-oriented information systems: Problem analysis, critical success } \\
\text { factors, and implications }\end{array}$ & $\begin{array}{l}\text { Mutschler, Bela; Reichert, Manfred; Bumil- } \\
\text { ler, Johannes }\end{array}$ & 2008 & 4,90 \\
\hline 43 & 45 & The ERP challenge in China: a resource-based perspective & $\mathrm{He}, \mathrm{X}$ & 2004 & 3,21 \\
\hline 44 & 44 & $\begin{array}{l}\text { Understanding misalignment and cascading change of ERP implementation: a stage view of process } \\
\text { analysis }\end{array}$ & Wei, HL; Wang, ETG; Ju, PH & 2005 & 3,38 \\
\hline 45 & 43 & Identification and classification of ERP critical failure factors in Iranian industries & $\begin{array}{l}\text { Amid, Amin; Moalagh, Morteza; Ravasan, } \\
\text { Ahad Zare }\end{array}$ & 2012 & 7,17 \\
\hline 46 & 43 & TQM-A predecessor of ERP in & Li, Ling; Markowski, Carol; $\mathrm{Xu}, \mathrm{Li}$; et al. & 2008 & 4,30 \\
\hline 47 & 43 & Fuzzy modeling Enterprise Resource Planning tool selection & Bueno, Salvador; Salmeron, Jose L. & 2008 & 4,30 \\
\hline 48 & 43 & CIOs' perspectives of critical success factors in ERP upgrade projects & Olson, D. L.; Zhao, F. & 2007 & 3,91 \\
\hline 49 & 42 & The role of organizational knowledge management in successful ERP implementation projects & Vandaie, Ramin & 2008 & 4,20 \\
\hline 50 & 42 & ERP and SCM systems integration: The case of a valve manufacturer in China & Bose, Indranil; Pal, Raktim; Ye, Alex & 2008 & 4,20 \\
\hline
\end{tabular}


Table 3. Most productive and influential institutions

\begin{tabular}{|c|c|c|c|c|c|c|c|c|c|c|c|}
\hline $\mathbf{R}$ & Institution & Country & TS & TC & H & TC/TS & $\geq 100$ & $\geq \mathbf{5 0}$ & $\geq 20$ & ARWU & QS \\
\hline 1 & Florida Atlantic U & US & 3 & 1006 & 3 & 335,33 & 2 & 1 & 0 & & - \\
\hline 2 & Wayne State U & US & 4 & 415 & 4 & 103,75 & 2 & 1 & 0 & $301-400$ & $461-470$ \\
\hline 3 & $\mathrm{U}$ of Manchester & UK & 2 & 382 & 2 & 191,00 & 1 & 0 & 1 & 38 & 34 \\
\hline 4 & $\mathrm{U}$ of Nebraska Lincoln & US & 4 & 328 & 4 & 82,00 & 2 & 0 & 2 & $151-200$ & $501-550$ \\
\hline 5 & City U of Hong Kong & $\mathrm{CN}$ & 5 & 310 & 3 & 62,00 & 2 & 0 & 0 & $201-300$ & 49 \\
\hline 6 & Eindhoven U of Technology & NL & 2 & 287 & 2 & 143,50 & 1 & 0 & 0 & $301-400$ & 104 \\
\hline 7 & Monash U & $\mathrm{AU}$ & 5 & 273 & 3 & 54,60 & 1 & 1 & 0 & 78 & 60 \\
\hline 8 & U of Melbourne & $\mathrm{AU}$ & 2 & 266 & 2 & 133,00 & 1 & 1 & 0 & 39 & 41 \\
\hline 9 & Boise State U & US & 2 & 265 & 2 & 132,50 & 1 & 0 & 1 & - & - \\
\hline 10 & Kansas State U & US & 4 & 228 & 3 & 57,00 & 1 & 1 & 0 & $501-600$ & $751-800$ \\
\hline 11 & Hong Kong Polytechnic U & $\mathrm{CN}$ & 4 & 216 & 3 & 54,00 & 1 & 0 & 1 & $201-300$ & 95 \\
\hline 12 & Accenture & US & 2 & 213 & 2 & 106,50 & 1 & 1 & 0 & - & - \\
\hline 13 & U Pablo Olavide & ES & 8 & 196 & 6 & 24,50 & 0 & 1 & 3 & - & - \\
\hline 14 & U of Colorado Denver & US & 3 & 189 & 2 & 63,00 & 1 & 1 & 0 & $301-400$ & 394 \\
\hline 15 & $\mathrm{U}$ of South Florida & US & 2 & 187 & 2 & 93,50 & 1 & 1 & 0 & $201-300$ & $501-550$ \\
\hline 16 & $\mathrm{U}$ of Sheffield & UK & 4 & 175 & 4 & 43,75 & 1 & 0 & 2 & $101-150$ & 82 \\
\hline 17 & U of Hull & UK & 2 & 171 & 2 & 85,50 & 1 & 0 & 0 & - & $601-650$ \\
\hline 18 & $\mathrm{U}$ of Leeds & UK & 2 & 154 & 2 & 77,00 & 0 & 2 & 0 & $101-150$ & 101 \\
\hline 19 & $\mathrm{U}$ of Colorado Health Science Center & US & 2 & 121 & 2 & 60,50 & 1 & 0 & 0 & - & - \\
\hline 20 & $\mathrm{U}$ of South Australia & $\mathrm{AU}$ & 5 & 110 & 5 & 22,00 & 0 & 1 & 0 & $501-600$ & 279 \\
\hline 21 & Oklahome State U Stillwater & US & 4 & 109 & 3 & 27,25 & 0 & 1 & 1 & $401-500$ & $801-1000$ \\
\hline 22 & U of Southern Queensland & $\mathrm{AU}$ & 3 & 107 & 3 & 35,67 & 0 & 1 & 1 & - & $751-800$ \\
\hline 23 & National Taiwan U of Science and Technology & TW & 3 & 97 & 2 & 32,33 & 0 & 1 & 0 & $701-800$ & 264 \\
\hline 24 & Ryreson U & $\mathrm{CA}$ & 6 & 92 & 4 & 15,33 & 0 & 0 & 3 & - & - \\
\hline 25 & National Central U & TW & 6 & 83 & 3 & 13,83 & 0 & 0 & 2 & $501-600$ & 391 \\
\hline 26 & Old Dominion U & US & 2 & 80 & 2 & 40,00 & 0 & 2 & 0 & $501-600$ & - \\
\hline 27 & Beijing Normal U & $\mathrm{CN}$ & 2 & 70 & 2 & 35,00 & 0 & 1 & 0 & $201-300$ & 256 \\
\hline 28 & Hong Kong Baptist U & $\mathrm{CN}$ & 2 & 70 & 2 & 35,00 & 0 & 1 & 0 & $601-700$ & 299 \\
\hline 29 & University of Adelaide & $\mathrm{AU}$ & 3 & 70 & 2 & 23,33 & 0 & 1 & 0 & $101-150$ & 109 \\
\hline 30 & National Chung Cheng U & TW & 5 & 68 & 4 & 13,60 & 0 & 0 & 2 & - & - \\
\hline 31 & U of Maryland College Park & US & 4 & 56 & 3 & 14,00 & 0 & 0 & 1 & 53 & 129 \\
\hline 32 & National Taiwan U & $\mathrm{TW}$ & 3 & 53 & 2 & 17,67 & 0 & 0 & 1 & $151-200$ & 76 \\
\hline 33 & Islamic Azad U & $\mathrm{IR}$ & 3 & 46 & 2 & 15,33 & 0 & 0 & 1 & - & - \\
\hline 34 & Shahid Beheshti U & $\mathrm{IR}$ & 3 & 46 & 2 & 15,33 & 0 & 0 & 1 & $701-800$ & $801-1000$ \\
\hline 35 & Allameh Tabatabai U & $\mathrm{IR}$ & 2 & 46 & 2 & 23,00 & 0 & 0 & 1 & - & - \\
\hline 36 & $\mathrm{U}$ of North Carolina & US & 2 & 45 & 2 & 22,50 & 0 & 0 & 1 & $201-300$ & 263 \\
\hline 37 & U of Ljubljana & SI & 7 & 42 & 3 & 6,00 & 0 & 0 & 0 & $401-500$ & $651-700$ \\
\hline 38 & Concordia U & $\mathrm{CA}$ & 2 & 42 & 2 & 21,00 & 0 & 0 & 1 & $401-500$ & $431-440$ \\
\hline 39 & Institut National Des Sciences Appliquees de Lyon INSA & FR & 2 & 41 & 2 & 20,50 & 0 & 0 & 1 & - & $451-460$ \\
\hline 40 & U of Teheran & IR & 2 & 41 & 2 & 20,50 & 0 & 0 & 1 & - & - \\
\hline 41 & $\mathrm{U}$ of Warwick & UK & 2 & 41 & 2 & 20,50 & 0 & 0 & 1 & $101-150$ & 57 \\
\hline 42 & Istanbul Teknik U & $\mathrm{TR}$ & 3 & 39 & 2 & 13,00 & 0 & 0 & 1 & - & $601-650$ \\
\hline 43 & Marmara U & TK & 2 & 39 & 2 & 19,50 & 0 & 0 & 1 & - & - \\
\hline 44 & Lappeenranta U of Technology & FI & 3 & 38 & 1 & 12,67 & 0 & 0 & 1 & - & $501-550$ \\
\hline 45 & U of Southampton & UK & 3 & 37 & 2 & 12,33 & 0 & 0 & 1 & $101-150$ & 102 \\
\hline 46 & U of Technology Sydney & $\mathrm{AU}$ & 2 & 35 & 1 & 17,50 & 0 & 0 & 1 & $301-400$ & 176 \\
\hline 47 & Aarhus U & DK & 2 & 33 & 2 & 16,50 & 0 & 0 & 1 & 65 & 119 \\
\hline 48 & National $U$ of Singapore & SG & 3 & 32 & 3 & 10,67 & 0 & 0 & 0 & 91 & 15 \\
\hline 49 & Bar Ilan U & IL & 2 & 32 & 2 & 16,00 & 0 & 0 & 0 & & $551-600$ \\
\hline 50 & Brunel U & UK & 4 & 29 & 3 & 7,25 & 0 & 0 & 0 & $401-500$ & 346 \\
\hline
\end{tabular}

Abbreviations: Available in Table 1 and 2 except for: $\mathrm{H}=\mathrm{h}$-index; TC/TS = Citations per study; ARWU and QS = Ranking in the general ARWU and QS university rankings. 
Table 4. Most productive and influential authors

\begin{tabular}{|c|c|c|c|c|c|c|c|c|c|c|}
\hline $\mathbf{R}$ & Name & Institution & Country & TS & TC & TC/TS & $\mathbf{H}$ & $\geq 100$ & $\geq \mathbf{5 0}$ & $\geq \mathbf{2 0}$ \\
\hline 1 & Liang, $\mathrm{HG}$ & Florida Atlantic U & United States & 2 & 930 & 465,00 & 2 & 2 & 0 & 0 \\
\hline 2 & Xue, YJ & Florida Atlantic U & United States & 2 & 930 & 465,00 & 2 & 2 & 0 & 0 \\
\hline 3 & $\mathrm{Hu}, \mathrm{Q}$ & Iowa State U & United States & 3 & 922 & 307,33 & 3 & 1 & 1 & 1 \\
\hline 4 & Somers, TM & Wayne State U & United States & 3 & 410 & 136,67 & 3 & 2 & 1 & 0 \\
\hline 5 & Nah, FFH & Missouri U of Science \& Technology & United States & 4 & 285 & 71,25 & 3 & 2 & 0 & 1 \\
\hline 6 & Gattiker, TF & Boise State U & United States & 2 & 265 & 132,50 & 2 & 1 & 0 & 1 \\
\hline 7 & Law, CCH & Hong Kong Polytechnic U & China & 2 & 214 & 107,00 & 2 & 1 & 0 & 1 \\
\hline 8 & Salmeron, JL & U Pablo de Olavide & Spain & 7 & 196 & 28,00 & 6 & 0 & 1 & 3 \\
\hline 9 & Gunasekaran, A & U of Massachusetts Dartmouth & United States & 2 & 194 & 97,00 & 2 & 1 & 0 & 1 \\
\hline 10 & Bhattacherjee, A & U of South Florida & United States & 2 & 187 & 93,50 & 2 & 1 & 1 & 0 \\
\hline 11 & Karimi, J & U of Colorado Denver & United States & 2 & 187 & 93,50 & 2 & 1 & 1 & 0 \\
\hline 12 & Abthorpe, MS & Nottingham Trent $\mathrm{U}$ & United Kingdom & 1 & 169 & 169,00 & 1 & 1 & 0 & 0 \\
\hline 13 & Burgess, TF & $\mathrm{U}$ of Leads & United Kingdom & 2 & 154 & 77,00 & 2 & 0 & 2 & 0 \\
\hline 14 & King, SF & U of Leads & United Kingdom & 2 & 154 & 77,00 & 2 & 0 & 2 & 0 \\
\hline 15 & Koh, SCL & U of Sheffield & United Kingdom & 2 & 138 & 69,00 & 2 & 1 & 0 & 1 \\
\hline 16 & Bueno, $\mathrm{S}$ & U Pablo de Olavide & Spain & 3 & 99 & 33,00 & 2 & 0 & 1 & 1 \\
\hline 17 & Lopez, C & U Pablo de Olavide & Spain & 4 & 92 & 23,00 & 4 & 0 & 0 & 2 \\
\hline 18 & $\mathrm{Li}, \mathrm{L}$ & Old Dominion U & United States & 2 & 80 & 40,00 & 2 & 0 & 0 & 2 \\
\hline 19 & Markowski, C & Old Dominion U & United States & 2 & 80 & 40,00 & 2 & 0 & 0 & 2 \\
\hline 20 & $\mathrm{Xu}, \mathrm{L}$ & Old Dominion U & United States & 2 & 80 & 40,00 & 2 & 0 & 0 & 2 \\
\hline 21 & Sheu, C & Kansas State U & United States & 2 & 79 & 39,50 & 2 & 0 & 1 & 0 \\
\hline 22 & Yen, HR & Kansas State U & United States & 2 & 79 & 39,50 & 2 & 0 & 1 & 0 \\
\hline 23 & Ram, J & U South Australia & Australia & 5 & 75 & 15,00 & 3 & 0 & 1 & 0 \\
\hline 24 & $\mathrm{Wu}, \mathrm{ML}$ & United International College & China & 3 & 75 & 25,00 & 3 & 0 & 1 & 0 \\
\hline 25 & Wang, ETG & National Central U & Taiwan & 3 & 70 & 23,33 & 2 & 0 & 0 & 2 \\
\hline 26 & Dezdar, $\mathrm{S}$ & Universiti Malaya & Malaysia & 2 & 61 & 30,50 & 1 & 0 & 1 & 0 \\
\hline 27 & Plaza, M & Ryreson U & Canada & 4 & 59 & 14,75 & 3 & 0 & 0 & 2 \\
\hline 28 & Corkindale, D & U South Australia & Australia & 4 & 56 & 14,00 & 2 & 0 & 1 & 0 \\
\hline 29 & Rohlf, K & Ryreson U & Canada & 2 & 47 & 23,50 & 2 & 0 & 0 & 2 \\
\hline 30 & Ravasan, AZ & Allameh Tabataba'i U & Iran & 2 & 46 & 23,00 & 2 & 0 & 0 & 1 \\
\hline 31 & $\mathrm{Wu}, \mathrm{LC}$ & National Chung Hsing U & Taiwan & 2 & 45 & 22,50 & 2 & 0 & 0 & 1 \\
\hline 32 & Botta-Genoulaz, V & Institut National des Sciences Appliquees de Lyon (INSA) & France & 2 & 41 & 20,50 & 2 & 0 & 0 & 1 \\
\hline 33 & Denle, D & Oklahoma State U & United States & 3 & 40 & 13,33 & 2 & 0 & 0 & 1 \\
\hline 34 & Kilic, HS & Mamara U & Turkey & 2 & 39 & 19,50 & 2 & 0 & 0 & 1 \\
\hline 35 & Skibniewski, MJ & U of Maryland College Park & United States & 3 & 37 & 12,33 & 3 & 0 & 0 & 1 \\
\hline 36 & Zaim, $\mathrm{S}$ & Istanbul Teknik U & Turkey & 3 & 37 & 12,33 & 2 & 0 & 0 & 1 \\
\hline 37 & Ojiako, U & U of Southampton & United Kingdom & 2 & 34 & 17,00 & 2 & 0 & 0 & 1 \\
\hline 38 & Ngwenyama, $\mathrm{O}$ & Ryreson U & Canada & 2 & 33 & 16,50 & 2 & 0 & 0 & 1 \\
\hline 39 & Ghosh, S & U of Maryland College Park & United States & 2 & 32 & 16,00 & 2 & 0 & 0 & 0 \\
\hline 40 & Shaul, L & Bar Ilan U & Israel & 2 & 32 & 16,00 & 2 & 0 & 0 & 0 \\
\hline 41 & Tauber, D & Bar Ilan U & Israel & 2 & 32 & 16,00 & 2 & 0 & 0 & 0 \\
\hline 42 & $\mathrm{Ku}, \mathrm{CY}$ & National Chiao Tung U & Taiwan & 3 & 29 & 9,67 & 2 & 0 & 0 & 1 \\
\hline 43 & Lin, WT & National Taiwan U & Taiwan & 2 & 29 & 14,50 & 2 & 0 & 0 & 0 \\
\hline 44 & Yeh, TM & Diwan U & Taiwan & 2 & 29 & 14,50 & 2 & 0 & 0 & 0 \\
\hline 45 & Jiang, JJ & U of Central Florida & United States & 2 & 26 & 13,00 & 1 & 0 & 0 & 1 \\
\hline 46 & Klein, G & $\mathrm{U}$ of Colorado at Colorado Springs & United States & 2 & 26 & 13,00 & 1 & 0 & 0 & 1 \\
\hline 47 & Adam, $\mathrm{F}$ & U College Cork & Ireland & 1 & 25 & 25,00 & 1 & 0 & 0 & 1 \\
\hline 48 & Soja, $P$ & Cracow $\mathrm{U}$ of Economics & Poland & 3 & 24 & 8,00 & 3 & 0 & 0 & 0 \\
\hline 49 & Kamal, MM & Brunel U & United Kingdom & 2 & 24 & 12,00 & 2 & 0 & 0 & 0 \\
\hline 50 & Chang, SI & National Chung Cheng $U$ & Taiwan & 2 & 21 & 10,50 & 1 & 0 & 0 & 1 \\
\hline
\end{tabular}

Abbreviations available in Table 1, 3 and 3. 
Table 5. Most productive and influential countries

\begin{tabular}{|c|c|c|c|c|c|c|c|c|c|c|c|}
\hline $\mathbf{R}$ & Country & TS & TC & H & $\mathrm{C} / \mathrm{S}$ & Pop & TS/Pop & TC/Pop & $\geq 100$ & $\geq \mathbf{5 0}$ & $\geq \mathbf{2 0}$ \\
\hline 1 & USA & 77 & 4083 & 29 & 53,03 & 323127,51 & 0,24 & 12,64 & 11 & 9 & 19 \\
\hline 2 & United Kingdom & 34 & 1613 & 16 & 47,44 & 65637,24 & 0,52 & 24,57 & 5 & 2 & 8 \\
\hline 3 & Canada & 18 & 1106 & 9 & 61,44 & 36286,43 & 0,50 & 30,48 & 1 & 1 & 6 \\
\hline 4 & China & 20 & 736 & 10 & 36,80 & 1378665 & 0,01 & 0,53 & 3 & 2 & 3 \\
\hline 5 & South Korea & 8 & 591 & 6 & 73,88 & 51245,71 & 0,16 & 11,53 & 1 & 1 & 1 \\
\hline 6 & Taiwan & 31 & 568 & 13 & 18,32 & 23113,99 & 1,34 & 24,57 & 0 & 3 & 6 \\
\hline 7 & Australia & 23 & 561 & 10 & 24,39 & 24127,16 & 0,95 & 23,25 & 1 & 3 & 3 \\
\hline 8 & Saudi Arabia & 7 & 367 & 4 & 52,43 & 32275,69 & 0,22 & 11,37 & 1 & 0 & 0 \\
\hline 9 & Netherlands & 5 & 303 & 4 & 60,60 & 17018,41 & 0,29 & 17,80 & 1 & 0 & 0 \\
\hline 10 & Spain & 15 & 210 & 6 & 14,00 & 46443,96 & 0,32 & 4,52 & 0 & 1 & 3 \\
\hline 11 & Italy & 8 & 186 & 5 & 23,25 & 60600,59 & 0,13 & 3,07 & 1 & 0 & 0 \\
\hline 12 & Germany & 12 & 105 & 5 & 8,75 & 82667,68 & 0,15 & 1,27 & 0 & 0 & 1 \\
\hline 13 & Singapore & 5 & 105 & 4 & 21,00 & 5607,28 & 0,89 & 18,73 & 0 & 1 & 0 \\
\hline 14 & Iran & 11 & 93 & 3 & 8,45 & 80277,42 & 0,14 & 1,16 & 0 & 0 & 2 \\
\hline 15 & Malaysia & 5 & 91 & 3 & 18,20 & 31187,26 & 0,16 & 2,92 & 0 & 1 & 1 \\
\hline 16 & Switzerland & 4 & 86 & 2 & 21,50 & 8372,1 & 0,48 & 10,27 & 0 & 1 & 0 \\
\hline 17 & France & 7 & 85 & 4 & 12,14 & 66896,11 & 0,10 & 1,27 & 0 & 0 & 2 \\
\hline 18 & New Zealand & 5 & 59 & 2 & 11,80 & 4692,7 & 1,07 & 12,57 & 0 & 0 & 1 \\
\hline 19 & Turkey & 11 & 56 & 4 & 5,09 & 79512,43 & 0,14 & 0,70 & 0 & 0 & 1 \\
\hline 20 & Norway & 3 & 48 & 2 & 16,00 & 5232,93 & 0,57 & 9,17 & 0 & 0 & 1 \\
\hline 21 & Poland & 5 & 45 & 3 & 9,00 & 37948,02 & 0,13 & 1,19 & 0 & 0 & 0 \\
\hline 22 & Slovenia & 8 & 42 & 3 & 5,25 & 2064,84 & 3,87 & 20,34 & 0 & 0 & 0 \\
\hline 23 & Finland & 3 & 38 & 1 & 12,67 & 5495,1 & 0,55 & 6,92 & 0 & 0 & 1 \\
\hline 24 & Denmark & 4 & 37 & 3 & 9,25 & 5731,12 & 0,70 & 6,46 & 0 & 0 & 1 \\
\hline 25 & Israel & 3 & 33 & 2 & 11,00 & 8547,1 & 0,35 & 3,86 & 0 & 0 & 0 \\
\hline 26 & India & 12 & 32 & 3 & 2,67 & 1324171,35 & 0,01 & 0,02 & 0 & 0 & 0 \\
\hline 27 & Bangladesh & 1 & 27 & 1 & 27,00 & 162951,56 & 0,01 & 0,17 & 0 & 0 & 1 \\
\hline 28 & Ireland & 1 & 25 & 1 & 25,00 & 4773,1 & 0,21 & 5,24 & 0 & 0 & 1 \\
\hline 29 & Greece & 7 & 22 & 3 & 3,14 & 10746,74 & 0,65 & 2,05 & 0 & 0 & 0 \\
\hline 30 & Sweden & 2 & 16 & 1 & 8,00 & 9903,12 & 0,20 & 1,62 & 0 & 0 & 0 \\
\hline 31 & Austria & 2 & 12 & 2 & 6,00 & 8747,36 & 0,23 & 1,37 & 0 & 0 & 0 \\
\hline 32 & Sri Lanka & 1 & 11 & 1 & 11,00 & 21203 & 0,05 & 0,52 & 0 & 0 & 0 \\
\hline 33 & Portugal & 4 & 9 & 2 & 2,25 & 10324,61 & 0,39 & 0,87 & 0 & 0 & 0 \\
\hline 34 & Serbia & 3 & 7 & 1 & 2,33 & 7057,41 & 0,43 & 0,99 & 0 & 0 & 0 \\
\hline 35 & South Africa & 4 & 5 & 1 & 1,25 & 55908,86 & 0,07 & 0,09 & 0 & 0 & 0 \\
\hline 36 & Indonesia & 2 & 5 & 1 & 2,50 & 261115,46 & 0,01 & 0,02 & 0 & 0 & 0 \\
\hline 37 & Slovakia & 1 & 5 & 1 & 5,00 & 5428,7 & 0,18 & 0,92 & 0 & 0 & 0 \\
\hline 38 & Pakistan & 4 & 3 & 1 & 0,75 & 193203,48 & 0,02 & 0,02 & 0 & 0 & 0 \\
\hline 39 & Qatar & 2 & 3 & 1 & 1,50 & 2569,8 & 0,78 & 1,17 & 0 & 0 & 0 \\
\hline 40 & Croatia & 3 & 3 & 1 & 1,00 & 4170,6 & 0,72 & 0,72 & 0 & 0 & 0 \\
\hline 41 & Kuwait & 1 & 2 & 1 & 2,00 & 4052,58 & 0,25 & 0,49 & 0 & 0 & 0 \\
\hline 42 & Bosnia and Herzegovina & 1 & 1 & 1 & 1,00 & 3516,82 & 0,28 & 0,28 & 1 & 1 & 1 \\
\hline 43 & Brazil & 2 & 0 & 0 & 0,00 & 207652,86 & 0,01 & 0,00 & 0 & 0 & 0 \\
\hline 44 & Colombia & 1 & 0 & 0 & 0,00 & 48653,42 & 0,02 & 0,00 & 0 & 0 & 0 \\
\hline 45 & Namibia & 1 & 0 & 0 & 0,00 & 2479,71 & 0,40 & 0,00 & 0 & 0 & 0 \\
\hline 46 & Palestine & 1 & 0 & 0 & 0,00 & 4816,5 & 0,21 & 0,00 & 0 & 0 & 0 \\
\hline 47 & Thailand & 1 & 0 & 0 & 0,00 & 68863,51 & 0,01 & 0,00 & 0 & 0 & 0 \\
\hline 48 & United Arab Emirates & 1 & 0 & 0 & 0,00 & 9269,61 & 0,11 & 0,00 & 0 & 0 & 0 \\
\hline
\end{tabular}

Abbreviations available in Table 1, 2 and 3 except for: Pop = Population; TS/Pop = Studies per population; TC/Pop = Citations per Population. 
Table 6. Most influential Journals

\begin{tabular}{|c|c|c|c|c|c|c|c|c|}
\hline $\mathbf{R}$ & Name & TS & TC & $\mathbf{H}$ & TC/TS & $\geq 100$ & $\geq \mathbf{5 0}$ & $\geq 20$ \\
\hline 1 & MIS Quarterly & 3 & 1143 & 3 & 381,00 & 2 & 1 & 0 \\
\hline 2 & Information Management & 9 & 965 & 7 & 107,22 & 3 & 1 & 2 \\
\hline 3 & European Journal of Operational Research & 3 & 866 & 3 & 288,67 & 2 & 0 & 1 \\
\hline 4 & International Journal of Production Economics & 14 & 864 & 12 & 61,71 & 3 & 4 & 2 \\
\hline 5 & European Journal of Information Systems & 9 & 473 & 8 & 52,56 & 1 & 1 & 3 \\
\hline 6 & Computers in Industry & 12 & 422 & 7 & 35,17 & 2 & 0 & 1 \\
\hline 7 & Journal of Computer Information Systems & 12 & 407 & 7 & 33,92 & 1 & 2 & 3 \\
\hline 8 & IEEE Software & 1 & 351 & 1 & 351,00 & 0 & 0 & 0 \\
\hline 9 & Industrial Management Data Systems & 8 & 277 & 6 & 34,63 & 0 & 3 & 1 \\
\hline 10 & International Joumal of Production Research & 8 & 271 & 7 & 33,88 & 1 & 0 & 4 \\
\hline 11 & Enterprise Information Systems & 15 & 211 & 6 & 14,07 & 0 & 1 & 3 \\
\hline 12 & Journal of Management Information Systems & 4 & 201 & 3 & 50,25 & 1 & 1 & 0 \\
\hline 13 & International Journal of Information Management & 6 & 185 & 4 & 30,83 & 0 & 2 & 1 \\
\hline 14 & Journal of Information Technology & 2 & 184 & 1 & 92,00 & 1 & 0 & 0 \\
\hline 15 & Information Systems Journal & 6 & 179 & 6 & 29,83 & 0 & 0 & 4 \\
\hline 16 & Decision Support Systems & 4 & 143 & 3 & 35,75 & 1 & 0 & 0 \\
\hline 17 & International Journal of Human Computer Interaction & 2 & 141 & 1 & 70,50 & 1 & 0 & 0 \\
\hline 18 & International Journal of Operations Production Management & 4 & 110 & 4 & 27,50 & 0 & 1 & 1 \\
\hline 19 & Information Systems Management & 8 & 108 & 5 & 13,50 & 0 & 1 & 0 \\
\hline 20 & Industrial Marketing Management & 1 & 84 & 1 & 84,00 & 0 & 1 & 0 \\
\hline 21 & Journal of Systems and Software & 2 & 79 & 2 & 39,50 & 0 & 0 & 2 \\
\hline 22 & Supply Chain Management an International Journal & 2 & 77 & 2 & 38,50 & 0 & 1 & 0 \\
\hline 23 & IEEE Transactions on Engineering Management & 3 & 65 & 3 & 21,67 & 0 & 0 & 2 \\
\hline 24 & ACM Computing Surveys & 2 & 59 & 2 & 29,50 & 0 & 0 & 1 \\
\hline 25 & Computer Standards Interfaces & 3 & 52 & 2 & 17,33 & 0 & 0 & 1 \\
\hline 26 & Expert Systems with Applications & 3 & 50 & 3 & 16,67 & 0 & 0 & 1 \\
\hline 27 & Production Planning Control & 8 & 43 & 4 & 5,38 & 0 & 0 & 0 \\
\hline 28 & Total Quality Management Business Excellence & 3 & 43 & 3 & 14,33 & 0 & 0 & 0 \\
\hline 29 & International Journal of Project Management & 4 & 41 & 3 & 10,25 & 0 & 0 & 0 \\
\hline 30 & Journal of the Association for Information Systems & 2 & 33 & 1 & 16,50 & 0 & 0 & 1 \\
\hline 31 & Journal of Database Management & 2 & 27 & 1 & 13,50 & 0 & 0 & 1 \\
\hline 32 & Journal of Global Information Management & 2 & 24 & 2 & 12,00 & 0 & 0 & 1 \\
\hline 33 & Behavior Information Technology & 2 & 23 & 2 & 11,50 & 0 & 0 & 0 \\
\hline 34 & Information Systems Frontiers & 3 & 17 & 2 & 5,67 & 0 & 0 & 0 \\
\hline 35 & International Journal of Technology Management & 2 & 15 & 2 & 7,50 & 0 & 0 & 0 \\
\hline 36 & Business Process Management Journal & 3 & 11 & 3 & 3,67 & 0 & 0 & 0 \\
\hline 37 & Journal of Enterprise Information Management & 7 & 9 & 2 & 1,29 & 0 & 0 & 0 \\
\hline 38 & Journal of Global Information Technology Management & 2 & 5 & 1 & 2,50 & 0 & 0 & 0 \\
\hline 39 & Ekonomska Istrazivanja Economic Research & 2 & 4 & 1 & 2,00 & 0 & 0 & 0 \\
\hline 40 & Computers and electronics in Agriculture & 1 & 4 & 1 & 4,00 & 0 & 0 & 0 \\
\hline 41 & Information Technology for Development & 2 & 3 & 1 & 1,50 & 0 & 0 & 0 \\
\hline 42 & Telematics and Informatics & 2 & 3 & 1 & 1,50 & 0 & 0 & 0 \\
\hline 43 & Project Management Journal & 2 & 2 & 1 & 1,00 & 0 & 0 & 0 \\
\hline 44 & Strojniski Vestnik Journal of Mechanical Engineering & 2 & 2 & 1 & 1,00 & 0 & 0 & 0 \\
\hline 45 & International Journal of Advanced Computer Science and Applications & 3 & 1 & 1 & 0,33 & 0 & 0 & 0 \\
\hline 46 & Communications of the Association for Information Systems & 2 & 1 & 1 & 0,50 & 0 & 0 & 0 \\
\hline 47 & South African Journal of Industrial Engineering & 2 & 1 & 1 & 0,50 & 0 & 0 & 0 \\
\hline 48 & International Journal of Enterprise Information Systems & 3 & 0 & 0 & 0,00 & 0 & 0 & 0 \\
\hline 49 & Benchmarking an International Journal & 2 & 0 & 0 & 0,00 & 0 & 0 & 0 \\
\hline 50 & Enterprise Information Systems Design Implementation and Management Organizational Applications & 2 & 0 & 0 & 0,00 & 0 & 0 & 0 \\
\hline
\end{tabular}

Abbreviations available in Table 1, 2 and 3 